\title{
Investigation of Methemoglobinemia Incidence Among Children Undergoing Circumcision Using Prilocaine
}

\author{
Prilokain Kullanılarak Sünnet Yapılan Çocuklarda \\ Methemoglobinemi Sıklığının Araştırılması
}

\author{
• Yaşar TOPAL ${ }^{1}{ }^{\bullet}$ Hasan DELIKTAŞ ${ }^{2},{ }^{\oplus}$ Hatice TOPAL ${ }^{1},{ }^{\bullet}$ Mehmet ÇETINKAYA ${ }^{2},{ }^{\bullet}$ Can Naci KOCABAŞ ${ }^{1}$
}

${ }^{1}$ Muğla Sıtkı Koçman University Faculty of Medicine, Department of Pediatrics, Muğla, Turkey

${ }^{2}$ Muğla Sıtkı Koçman University Faculty of Medicine, Department of Urology, Muğla, Turkey

\begin{abstract}
Objective: Methemoglobinemia is a clinical entity characterized by substitution of ferrous iron ( $\mathrm{Fe}+2)$ in the hemoglobin structure by ferric iron $(\mathrm{Fe}+3)$ that lacks oxygen carrying capacity. Acquired methemoglobinemia may occur due to oxidant substances and drugs, of which local anesthetics constitute an important group. In this study the incidence of prilocaine-induced methemoglobinemia was studied.
\end{abstract}

Material and Methods: This study was performed on children who presented to the urology department for circumcision in 2013. Methemoglobin levels were measured prior to and after prilocaine injection.

Results: The study enrolled 74 children aged 6 months to 12 years. Five patients with a known hematological disorder or those with chronic disorders were excluded. Of the cases, $20.2 \%$ were found to have methemoglobinemia but none had symptoms. Mean preoperative and postoperative incidences of methemoglobin were $0.71 \%$ and $1.80 \%$, respectively. Methemoglobin level was reduced as age of the patient increased.

Conclusion: The risk of methemoglobinemia should be considered with local anesthetic agents widely used in clinical practice, particularly in small age groups.

Key Words: Circumcision, Male children, Methemoglobinemia, Prilocaine

\section{Öz}

Amaç: Methemoglobinemi, hemoglobindeki ferröz demirin ( $\mathrm{Fe}+2)$ yerini oksijen taşıma kapasitesi olmayan ferrik demirin (Fe+3) alması ile karakterize bir klinik durumdur. Edinsel methemoglobinemi, oksidan maddeler ve ilaçlara bağlı olarak ortaya çıkabilirken, lokal anestezikler ilaçlar arasında önemli bir grubu oluşturur. Bu çalışmada prilokaine bağlı methemoglobinemi sıklığı araşıııılmıştır.

Gereç ve Yöntemler: Çalıșma 2013 yllında üroloji polikliniğine sünnet amacıyla bașvuran çocuklar arasında yapıldı. Prilokain öncesi ve sonrası methemoglobin düzeyleri araştıııldı.

Bulgular: Çalışmaya yaşları 6 ay ile 12 yaş arasında değişen 74 çocuk dahil edildi. Bilinen hematolojik ve kronik hastalığı olanlar çıkarılmışıı. Olguların \%20.2'sinde methemoglobinemi saptanırken semptomatik olan olgu saptanmadı. Methemoglobin ortalaması \%0.71, postoperatif \%1.80 olarak saptandı. Yașın artışına parelel olarak methemoglobin düzeyinin azaldığı gözlendi.

Sonuç: Günlük pratikte sıklıkla kullanılan lokal anesteziklerin kullanımı ile özellikle küçük yaş grubunda methemoglobinemi riski göz önünde bulundurulmalıdır.

Anahtar Sözcükler: Sünnet, Erkek çocuklar, Methemoglobinemi, Prilokain

\section{INTRODUCTION}

Methemoglobinemia is a clinical entity characterized by substitution of ferrous iron $(\mathrm{F}+2)$ in the hemoglobin structure by ferric $(F+3)$ iron that lacks oxygen carrying capacity (1). Methemoglobinemia occurs after the intake of an oxidizing substance. Serum Methemoglobin concentration is typically kept at the range of $1 \%$ to $2 \%$ by the cytochrome b5 methemoglobin reductase enzyme. This enzyme is dependent on adenine dinucleotide. The clinical effect of methemoglobinemia is functional anemia that results from the inability of methemoglobin to bind oxygen (2). 
Extremely high levels of methemoglobin result from exposure to various oxidant substances or drugs such as local anesthetics and dapsone. Local anesthetics, one of the indirect oxidants, can also be seen in normal standard doses, but methemoglobinemia is usually seen in high doses (3-6). Methemoglobinemia may also occur due to prilocaine, a widely used local anesthetic agent (4). Benzocaine-induced methemoglobinemia may be encountered in one of every 700 cases (8). Apart from local anesthetics, other drugs such as nitroglycerin, dapsone, phenacetin, phenytoin, primaquine, sulphonamides, and prilocaine metabolites are also known to cause methemoglobinemia (9). Cyanosis is observed at a methemoglobin level above 15\%; at levels exceeding $45 \%$, clinical signs and symptoms as serious as acidosis, cardiac arrhythmia, dyspnea, seizures, and coma (10). Methemoglobinemia associated with EMLA (eutectic mixture of local anesthetics), a local anesthetic mixture of prilocaine and lidocaine, is not widely known, a report issued by American Association of Poison Control Centers in 2012 states that no case of EMLA-induced methemoglobinemia has yet reported (11).

Cyanosis occurring after local anesthesia is an important clue for diagnosis. In addition to clinical signs, lower saturation readings despite high arterial oxygen pressure also suggest methemoglobinemia (12). We aimed to determine methemoglobinemia incidence among children undergoing circumcision using prilocaine anesthesia.

\section{MATERIALS and METHOD}

Our study was conducted among healthy children presented for circumcision within one-month period. Patients with a known hematological disorder or those with chronic disorders were excluded. A general examination was performed before circumcision in every patient, and routine hemogram and blood gas analysis $(0.5 \mathrm{ml}$ blood was taken from the patient with a syringe and analyzed without waiting) was done to check preoperative methemoglobin levels (Instrument Laboratory GEM PREMIER 3.000, Italy).

Methemoglobin level is known to not exceed $1-2 \%$ in healthy persons. We accepted a threshold value of $2 \%$ to define methemoglobinemia (13).

Prior to circumcision prilocaine was used at a dose of $1 \mathrm{mg} /$ $\mathrm{kg} /$ dose as the local anesthetic agent (Cytanest 2\%; Astra Zeneca, İstanbul, Turkey). Methemoglobin level was rechecked 1 hour after circumcision. All children were monitored for 6 hours postoperatively; and then discharged after a general examination was performed.

\section{Statistical analysis}

The comparison of post-circumcision (postoperative) and pre-circumcision (preoperative) methemoglobin levels were performed with Matched-pairs t-test or Wilcoxon signed-rank test, considering data distribution. Patients with methemoglobin levels below and above $2 \%$ were compared with respect to age, hemoglobin, postoperative and preoperative levels using Welch t-test or Wilcoxon-Mann-Whitney test. Descriptive statistics were presented as mean \pm standard deviation, median, minimum and maximum. The correlation between study parameters was tested using Spearman's $\rho$ (rho) correlation analysis. A P value of less than 0.05 was considered statistically significant. All analyses were carried out using the statistical software R.

\section{RESULTS}

This study involves 69 children. The age range was 6 months to 12 years, with a mean of $7.08 \pm 2.39$ years ( $\mathrm{min}=6$ months, $\max =12$ years). The mean hemoglobin level was $12.57 \pm$ $1.01 \mathrm{gr} / \mathrm{dl}$ ( $\min =9.8, \max =14.9$ ). The mean preoperative methemoglobin level was $0.72 \pm 0.31$ ( $\min =0.2$, $\max =1.9$ ) and the mean postoperative methemoglobin level was $1.80 \pm 1.47$ $(\min =0.6, \max =11.6)$. Methemoglobinemia was diagnosed in 14 (20.2\%) patients postoperatively. There was a medium inverse correlation between age and postoperative methemoglobin level (Pearson Correlation test, $r=-0.49$, medium $p<0.001$ actual $p$ value). In parallel to age increase, there occurred a reduction in the methemoglobin levels (Figure 1). The mean age of patients with a methemoglobin level below 2\% was 7.64 (St. deviation \pm 1.68 ) years while those who had a methemoglobin level above $2 \%$ had a mean age of 4.8 years (St. deviation \pm 3.41 ) $(p=0.001$, Mann-Whithey $U$ test). There was weak a correlation between hemogram and postoperative methemoglobin level (Pearson Correlation test, $r=-0.22, p=0.069$ ). While the mean hemoglobin concentration was 12.7 (St. deviation \pm 1.02 ) gr/ dl in those with a postoperative methemoglobin level below $2 \%$, those who had a methemoglobin concentration exceeding $2 \%$ had a mean hemoglobin count of 11.99 (St. deviation \pm $0.78) \mathrm{gr} / \mathrm{dl}$ ( $\mathrm{p}=0.007$, t-test) (Figure 2). In our patients with methemoglobinemia were detected any clinical sign and symptom.

\section{DISCUSSION}

Acquired methemoglobinemia caused by local anesthetics is an important clinical problem. Prilocaine, benzocaine, lidocaine, and tetracaine are the most notable local anesthetic agents shown to induce methemoglobinemia (5). Among these, prilocaine is known to induce methemoglobinemia through its ortho toluidine metabolite (14). Erythrocytes being exposed to more antioxidant than they can handle may cause methemoglobinemia. Methemoglobinemia risk is known to increase in parallel to an increase in local anesthetic dose (4, 15).

In our study about $1 / 5$ of children who were circumcised under prilocaine local anesthesia had a methemoglobin level 


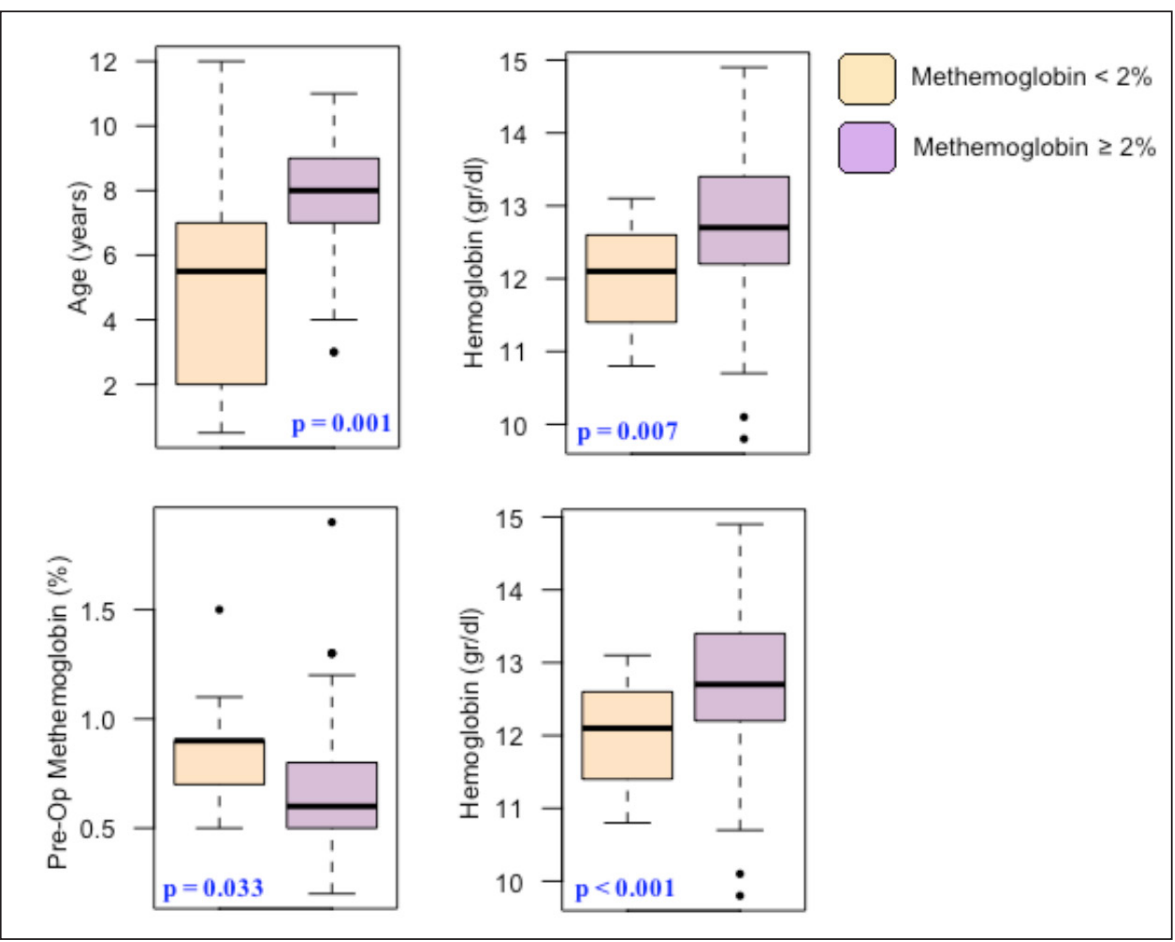

Figure 1: Patients with methemoglobin levels below $2 \%$ vs above $2 \%$ for age hemoglobin, pre-op and post-op methemoglobin values

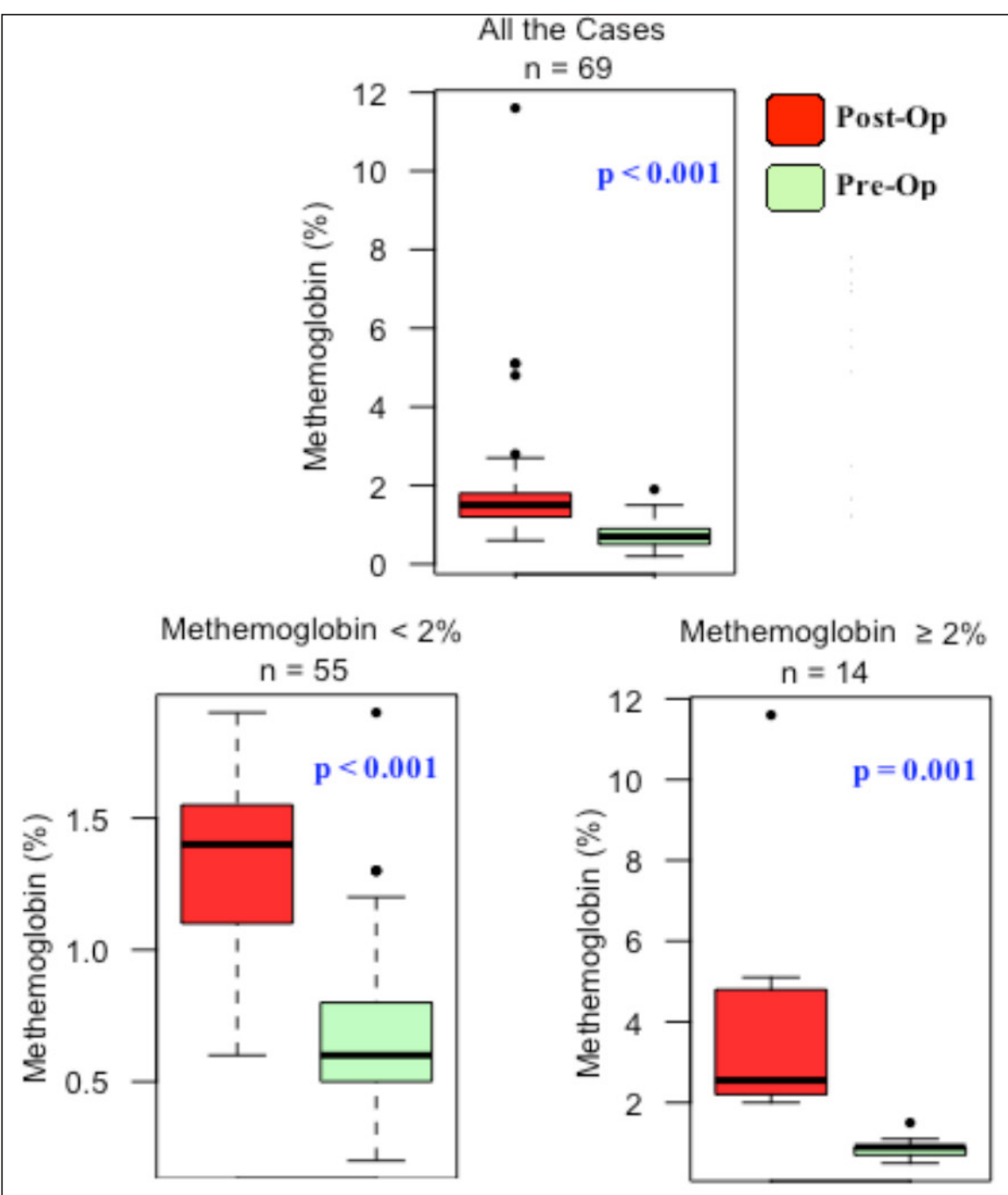

Figure 2: Post-op and pre-op methemoglobin levels. 
exceeding $2 \%$, and the mean postoperative methemoglobin level was $1.80 \pm 1.47 \%$. We used a standard prilocaine dose of $1 \mathrm{mg} / \mathrm{kg}$ in circumcised children. In a study where prilocaine was used as local anesthetic agent $15.2 \%$ of 37 children developed methemoglobinemia, and the corresponding value for the adult group was $12.7 \%$ (16). In another study where benzocaine spray was used as local anesthetic for endoscopic examination in 401 cases, methemoglobinemia incidence was $1.4 \%$ while the corresponding figure for the control gender was $1 \%$ (17). A higher figure found in our study may result from a higher prevalence of G6PD enzyme deficiency in addition to those of thalassemia and hemoglobinopathies in our region (18). The risk of methemoglobinemia is known to increase as a result of a reduction in the enzyme of cytochrome b5 methemoglobin reductase in persons with G6PD deficiency (19).

Mean post-circumcision methemoglobin level was significantly greater than the mean pre-circumcision level $(P<0.001)$. Pediatric studies on prilocaine-induced methemoglobinemia are mostly case reports. We did not encounter any study on the incidence of subclinical methemoglobinemia. No significant methemoglobin increase was observed in patients undergoing upper endoscopic examination using benzocaine as local anesthetic agent (17). In newborns, mean methemoglobin levels have been reported between $0.44 \%$ and $1.3 \%$ after local prilocaine applications (EMLA -eutectic mixture of local anesthetics-creme) for various procedures $(20,21)$.

Incomplete maturation of NADPH meth-reductase enzyme, greater fetal hemoglobin concentration, and fetal hemoglobin being more readily oxidized are all held responsible for a greater methemoglobinemia risk in this population (22). Our study also demonstrated that methemoglobin level gradually but significantly dropped as age increased $(p<0.05)$. Amr ElHusseini et al reported that the risk of methemoglobinemia was higher among children than adults (16). Particularly infants younger than 4 months of age are reportedly more prone to methemoglobinemia risk owing to reduced activity and concentration of NADH methemoglobin reductase (23). Anemia may be a risk factor for methemoglobinemia. Anemic patients are more prone to methemoglobinemia due to a lower functional hemoglobin reserve (24). In a study where patients undergoing various surgical procedures were followed for a period of 10 years, mean hemoglobin was found $12.4 \mathrm{gr} / \mathrm{dl}$ and methemoglobinemia incidence $0.035 \%$.

Our study also confirmed that patients with a higher methemoglobin level had a lower mean hemoglobin level. This indicates an inverse correlation between hemoglobin and methemoglobinemia, corroborating previous reports. However, the absence of any patient with severe anemia or excessively high methemoglobin level may have been responsible for our patients being asymptomatic.

The lack of information whether patients consumed packed food, undercooked contaminated food (spinach, beet), or took non-local anesthetic medications like dapsone is our study's limitation. Moreover, its single-center design and being conducted in a region where G6PD deficiency has formerly been reported to be prevalent are the other limitations.

In conclusion, subclinical methemoglobinemia is common with the use of local anesthetic agents widely used in clinical practice. A low hemoglobin level also increases the risk of methemoglobinemia.

\section{Compliance with Ethical Standards:}

Conflict of Interest: On behalf of all authors, the corresponding author states that there is no conflict of interest.

Ethical approval: All procedures performed in studies involving human participants were in accordance with the ethical standards of the institutional and/or national research committee and with the 1964 Helsinki declaration and its later amendments or comparable ethical standards.

Informed consent: Informed consent was obtained from all individual participants included in the study.

\section{REFERENCES}

1. Wright $\mathrm{RO}$, Lewander WJ, Woolf $\mathrm{AD}$. Methemoglobinemia: etiology, pharma-cology, and clinical management. Ann Emerg Med 1999;34:646-56.

2. Darling R, Roughton F. The effect of methemoglobin on the equilibrium between oxygen and hemoglobin. Am J Physiol 1942;137:56.

3. Kane GC, Hoehn SM, Behrenbeck TR, Mulvagh SL. Benzocaineinduced methemoglobinemia based on the Mayo Clinic experience from 28478 transesophageal echocardiograms: incidence, outcomes, and predisposing factors. Arch Intern Med 2007;167: 1977-82.

4. Vasters FG, Eberhart LH, Koch T, P Kranke, H Wulf, AM Morin. Risk factors for prilocaine-induced methaemoglobinaemia following peripheral regional anaesthesia. Eur J Anaesthesiol 2006;23:7605.

5. Trapp L, Will J. Acquired Methemoglobinemia Revisited. Dent Clin N Am 2010; 54:665-75.

6. Hegesh E, Hegesh J, Kaftory A. Congenital methemoglobinemia with a deficiency of cytochrome b5. N Engl J Med 1986;314:75761.

7. Coleman MD, Coleman NA. Drug-induced methaemoglobinaemia. Treatment issues. Drug Saf 1996;14:394-405.

8. Kreshak AA, Ly BT, Edwards WC, Carson SH. A 3-year-old boy with fever and oral lesions. Diagnosis: methemoglobinemia. Pediatr Ann 2009; 38: 613-16.

9. Khan NA, Kruse JA. Methemoglobinemia induced by topical anesthesia: a case report and review. Am J Med Sci 1999; 318: 415-8.

10. Goldfrank L, Flomenbaum N, Lewin N, Weisman R. Goldfrank's Toxicologic Emergencies. 6th ed. Stamford, CT: Appleton \& Lange; 1998 Mansouri A, Lurie AA. Concise review: methemoglobinemia. Am J Hematol 1993;42:7-12.

11. Bronstein AC, Spyker DA, Cantilena LR, Rumack BH, Dart RC. 2011 Annual report of the American Association of Poison Control Centers' National Poison Data System (NPDS): 29th Annual Report. Clin Toxicol (Phila) 2012;50:911-1164. 
12. Guay J. Methemoglobinemia related to local anesthetics: a summary of 242 episodes. Anesth Analg 2009;108:837-45.

13. Vallurupalli S, Manchanda S. Risk of acquired methemoglobinemia with different topical anesthetics during endoscopic procedures. Local Reg Anesth 2011;4:25-8.

14. Nishimura K. Methemoglobinemia due to local anesthetics. Osaka City Med J 1971;17:25-42.

15. Ash-Bernal R, Wise R, Wright SM. Acquired methemoglobinemia: a retrospective series of 138 cases at 2 teaching hospitals. Medicine (Baltimore) 2004;83:265-73.

16. Amr El-Husseini MD Nick Azarov MD. Is threshold for treatment of methemoglobinemia the same for all? A case report and literature review. Am J Emerg Med 2010;28: 748.e5-748.

17. Hall NM, Jones FJ, Ainsworth CR, Fincher RK. Methemoglobinemia in patients undergoing esophagogastroduodenoscopy: a randomized controlled trial. Mil Med 2013;178:701-4.

18. Aksu TA, Esen F, Dolunay S, Alıcıgüzel Y, Yücel G, Çalı Ş. Erytrocyte glucose-6-phosphate dehydrogenase deficiency in Antalya Province, Turkey: an epidemiologic and biochemical study. Am J Epidemiol 1990;131:1094-7.
19. Kinoshita A, Nakayama Y, Kitayama T, Tomita M. Simulation study of methemoglobin reduction in erythrocytes. Differential contributions of two pathways to tolerance to oxidative stress. FEBS J 2007;274:1449-58.

20. Law RM, Halpern S, Martins RF, Reich H, Innanen V, Ohlsson A. Measurement of methemoglobin after EMLA analgesia for newborn circumcision. Biol Neonate 1996; 70: 213-17.

21. Taddio A, Ohlsson A, Einarson Tr, Stevens B, Koren G. A systematic review of lidocaine-prilocaine cream (EMLA) in the treatment of acute pain in neonates. Pediatrics 1998;101:E1

22. Lehr J, Masters A, Pollack B. Benzocaine-induced methemoglobinemia in the pediatric population. $J$ Pediatr Nurs 2012;27:583-8.

23. Rechetzki KF, Henneberg R, da Silva PH, do Nascimento AJ. Reference values for methemoglobin concentrations in children. Rev Bras Hematol Hemoter 2012: 34:14-6.

24. Hsieh H-S, Jaffe E. The metabolism of methemoglobin in human erythrocytes. In: Stugenor D, ed. The red blood cell. New York: Academic Press1975. 